\title{
norden
}

\section{Fra drøm til virkelighed}

Om nordiske kompetencemål og didaktiske principper for undervisning i entreprenørskab

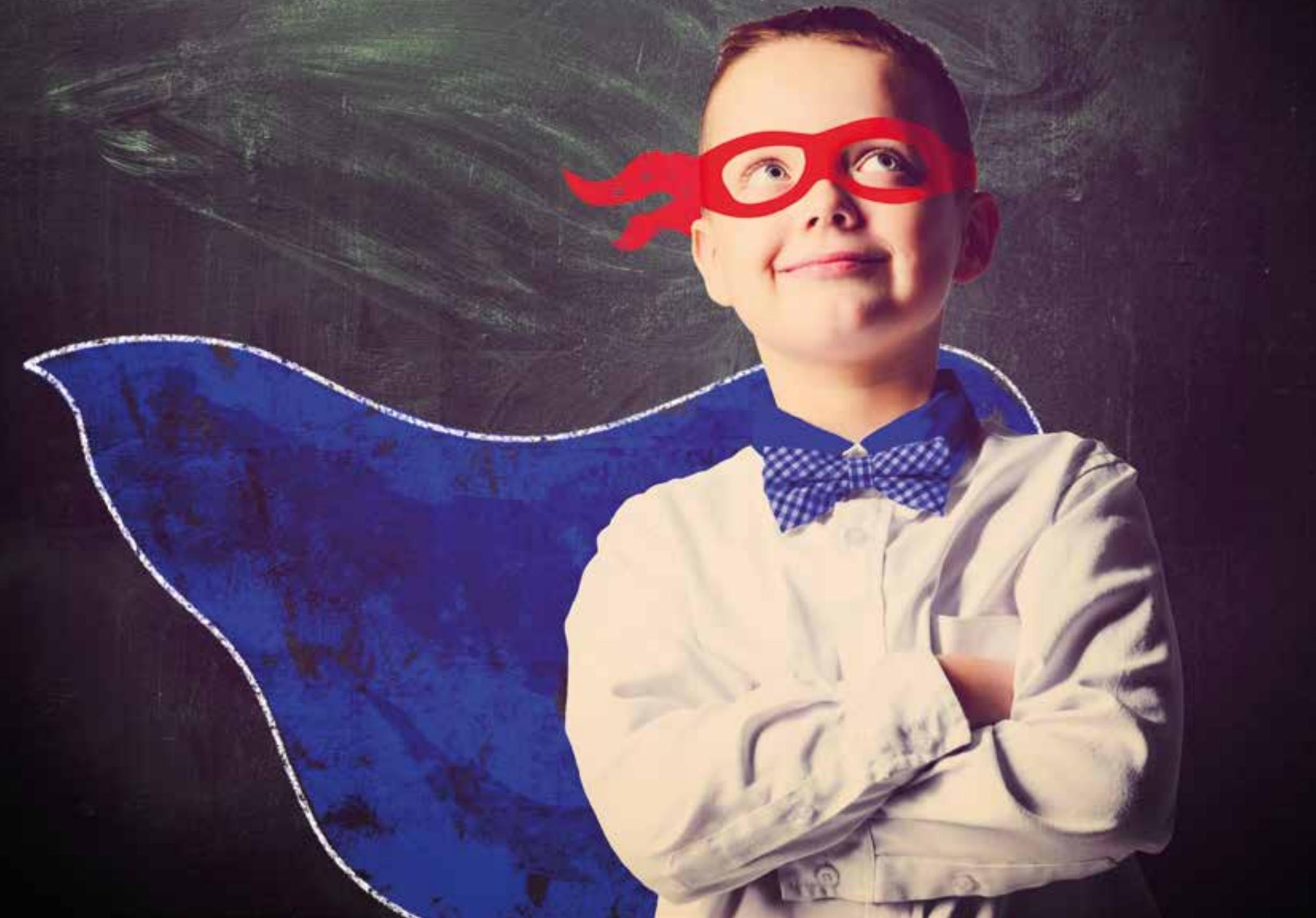


ISBN 978-92-893-4397-8 (PRINT)

ISBN 978-92-893-4398-5 (PDF)

http://dx.doi.org/10.6027/ANP2015-791

ANP 2015:791

(C) Nordisk Ministerråd 2015

Layout: Gitte Wejnold

Omslagsfoto: SignElements.com

Foto: SignElements.com

Tryk: Rosendahls-Schultz Grafisk

Oplag: 400

Skrift: Meta LF

Papir: Munken Polar

\section{Projektkoordinering:}

Morten Friis Møller, Nordisk Ministerråd

\section{Udarbejdet af:}

Anders Rasmussen og Anne Fritzner, Fonden for Entreprenørskab

\section{Nordisk referencegruppe:}

Peter Skoglöf og Ragnar Asbrink, Sverige. Charlotte Romlund Hansen, Danmark. Inger Karin Røe Ødegaard, Norge. Anna Mikander, Finland. Bjørk Ottarsdottir, Island. Jenny Lydersen, Færøerne. Bo Nygaard, Ålandsøerne. Karl Kristian Olsen, Grønland.

\section{Særlig tak til:}

Mette Birk, Ministeriet for børn, undervisning og ligestilling og Tine Madelung, Præstø Privatskole for kommentarer og kvalificering.

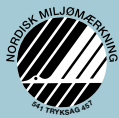

Printed in Denmark

Denne rapport er udgivet med finansiel støtte fra Nordisk Ministerråd. Indholdet i rapporten afspejler dog ikke nødvendigvis Nordisk Ministerråds synspunkter, meninger, holdninger eller anbefalinger.

www.norden.org/nordpub

\section{Det nordiske samarbejde}

Det nordiske samarbejde er en af verdens mest omfattende regionale samarbejdsformer. Samarbejdet omfatter Danmark, Finland, Island, Norge og Sverige samt Færøerne, Grønland og Åland.

Det nordiske samarbejde er både politisk, økonomisk og kulturelt forankret, og er en vigtig medspiller i det europæiske og internationale samarbejde. Det nordiske fællesskab arbejder for et stærkt Norden i et stærkt Europa.

Det nordiske samarbejde ønsker at styrke nordiske og regionale interesser og værdier i en global omverden. Fælles værdier landene imellem er med til at styrke Nordens position som en af verdens mest innovative og konkurrencedygtige regioner.

\section{Nordisk Ministerråd}

Ved Stranden 18

DK-1061 København K

Telefon (+45) 33960200

www.norden.org 


\section{Fra drøm til virkelighed}

Om nordiske kompetencemål og didaktiske principper for undervisning i entreprenørskab 


\section{Indledning}

Nordisk Ministerråd har i flere faser arbejdet for at styrke entreprenørskabskultur- og uddannelse i de nordiske lande. Globalisering, teknologisk udvikling, forandringshastighed og demografiske ændringer udfordrer såvel den nordiske velfærdsmodel som det enkelte individ. Derfor er der over tid opstået et behov for, at uddannelsessystemet kan forberede elever og studerende på et liv, hvor de har mulighed for at være aktive medskabere af fremtiden.

Nordisk Ministerråds prisbelønnede rapport "Entrepreneurship Education in the Nordic countries"1 og EU's "Final Report of the Thematic Working Group on Entrepreneurship Education" ${ }^{2}$ nævner behovet for at udvikle en kompetenceramme, som kan bygge bro imellem strategi, ledelse, praksis og læring. Samtidig kan en kompetenceramme skabe progression i undervisningen og gøre det tydeligt, hvad forskellen er på en elev, der har været involveret i entreprenørskabsundervisning og en elev, som ikke har. En Kompetenceramme skal muliggøre at undervisningen tager udgangspunkt i, hvad der skal læres fremfor i særlige aktiviteter eller processer. Nærværende kompetenceramme søger at indfri dette behov, med respekt for nordiske skoletraditioner og for den brede forståelse af entreprenørskab, der er opstået parallelt i de nordiske lande. Entreprenørskab er i nordisk skolesammenhæng rettet mod at give eleverne kompetencer, som kan anvendes i mange sammenhænge, personligt, socialt og samfundsmæssigt.

Kompetencerammen henvender sig til en lang række interessenter: Den er først og fremmest et redskab til lærere og praktikere som kan finde kompetence- og læringsmål samt didaktiske principper for undervisningen. Kompetencerammen henvender sig også til beslutningstagere, som skal skabe lovgivning og rammer for at entreprenørskabsundervisning kan finde sted. På samme måde henvender den sig til ledere der i dagligdagen skal understøtte strukturer og skabe miljøer samt pædagogisk udvikling så entreprenørskabsundervisning bliver en integreret del af grundskolen.

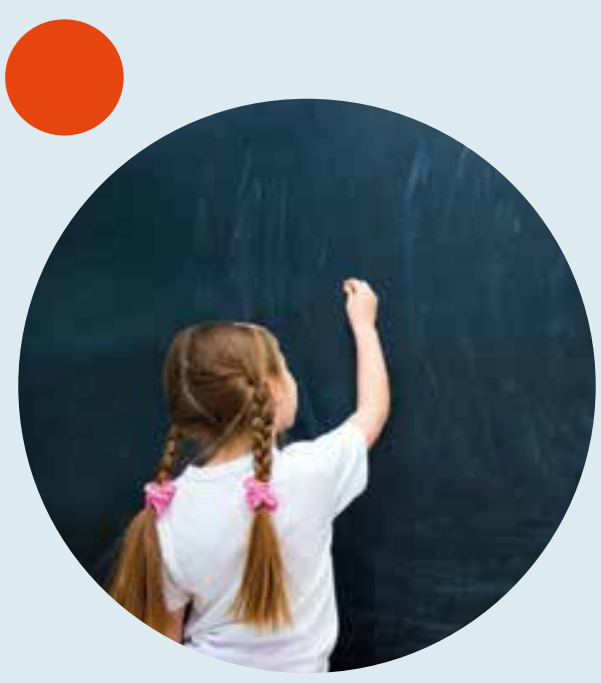




\section{Det særligt nordiske}

På trods af de nationale forskelle på skolerne i norden, er der også en lang række fællestræk. Dette angår dannelsesbegrebets betydning, indflydelsen fra den folkelige oplysningsbevægelse og reformpædagogikken og senest fokus på internationale sammenligninger og på evidens- og læringsmålstyret undervisning.

\section{Dannelse}

Dannelsesbegrebet har siden indførslen af offentlige skolesystemer været en del af den nordiske måde at tænke skole og uddannelse på. Dannelsesforståelsen dækker over, at der findes noget, som rækker udover fag og faglighed og som angår den principielt uafsluttede proces $i$ at blive et livsdueligt og myndigt menneske i en kulturel sammenhæng. I de nordiske skoler er dannelsesidealet beskrevet $i$ de overordnede formål for skolen. Dannelse og dannelsesidealer er dog ikke faste størrelser og varierer over tid på baggrund af skiftende politiske og kulturelle kontekster samt pædagogiske og filosofiske strømninger. Dannelse er således et dynamisk begreb, som har penduleret imellem fokus på personlig vækst og fokus på tilegnelsen af på forhånd udstukne faglige mål. ${ }^{3}$

${ }^{1}$ Nordisk Ministerråd (2012).

${ }^{2}$ Europæiske Kommission (2015).

${ }^{3}$ Gustavsson (1998) Dannelse i vor tid, Forlaget KLIM. 
De nordiske demokratier og velfærdsstater er således opstået i et nært samspil med et demokratisk dannelsesideal, hvor eleverne skal lære at tage stilling, handle, bidrage til et demokratisk samfund og agere som demokratiske medborgere. En del af dannelsesbegrebet angår kompetencerne til selvbestemmelse, socialt ansvar og evnen til at indgå i og være medskabere af et samfund. Denne forståelse ligger sig tæt op ad nordisk entreprenøriel dannelse og nærværende kompetenceramme. Dannelsesbegrebet udfordres af, at forståelsen af begrebet varierer og at det ofte kommer til at fremstå som modsætning til faglighed, uanset at faglighed altid har været en del af dannelsen. Desuden er det ofte utydeligt, hvad det er, der skal læres og tilegnes for at være "dannet". Nærværende kompetenceramme er et forsøg på at konkretisere og udfolde nogle af de entreprenørielle dannelseselementer som allerede findes i skolernes formål.

\section{Reformpædagogik}

Reformpædagogikken har haft stor indflydelse på den nordiske uddannelsestænkning og betydet, at den autoritære skole med hård disciplin og udenadslære er forsvundet. Uanset det nutidige fokus på faglighed og målbarhed, er undervisningen stadig centreret om barnet og tager oftest udgangspunkt i elevernes behov og interesser. Ligeledes er elevernes aktive deltagelse i læringen gennem projekt-, gruppe- og tværfagligt arbejde en del af nordiske skolers hverdag. Sammen med de folkelige oplysningsbevægelser har dette givet en form for nordisk "selvfølgelighed" som betyder, at der er en uformel og ligeværdig relation imellem lærer og elev, og at elevernes motivation, lyst og interesser tilgodeses $i$ undervisningen. ${ }^{4}$
Populært sagt har den frigørende og reformpædagogiske praksis sejret "ad helvede til", problemet i dag er således ikke den "ufrihed" som den frigørende pædagogik skulle råde bod på, men hvad vi aktuelt skal bruge frihed og frigørelse til. ${ }^{5}$ Entreprenørskabsundervisning kan ses som en videreudvikling af reformpædagogiske tanker, da den sigter imod at understøtte elevernes mulighed for at agere i samfundet, at tage vare på eget liv og karriere og at kunne iværksætte initiativer, der skaber værdi for andre, kulturelt, økonomisk og socialt. ${ }^{6}$ Entreprenørskabsundervisning er således ikke frigørende i klassisk forstand, men rettet imod at styrke elevens kompetencer til frit at kunne anvende de muligheder, der findes i livet og i verden.

\section{Fokus på læringsmål og monitorering}

De seneste år er målbare faglige resultater og internationale sammenligninger blevet en del af den politiske skoledagsorden og dermed også af de nordiske skolers hverdag. Samtidig har forskning, som viser at eleverne lærer mere såfremt undervisningen baseres på synlige læringsmål og på feedback fået stor indflydelse. ${ }^{7}$ Samlet set har dette givet anledning til en række reformer af skolesystemerne og af de krav, der stilles til skoler og lærere. Udviklingen er sket parallelt med indførelsen af strategierne for entreprenørskab. Problemet er, at når skolens fag i højere og højere grad bliver udspecificeret og målt, risikerer skolens overordnede formål, herunder de entreprenørielle elementer, at fremstå ukonkrete og uhåndterlige. Således er nærværende kompetenceramme et forsøg på at klargøre læringsmålene inden for entreprenørskab, så de kan gøres til genstand for undervisning, feedback og evaluering på lige fod med skolens fag. Kompetencerammen gør det muligt at fokusere på 


\section{Entreprenørielle kompetencer}

Kompetencerammen er bygget på den tilgængelige internationale forskning samt på de nordiske skoleformål og entreprenørskabsstrategier. En referencegruppe fra de 5 nordiske landes og de 3 selvstyreområder har medvirket til, at sikre, at rammen kan anvendes under nationale forhold. Kompetencebegrebet er inspireret af Illeris ${ }^{8}$ og forstås som:

\section{"Helhedsbetonede fornufts- og følelsesmæssigt forankrede kapaciteter, dispositioner og potentia- ler, der er relateret til mulige handlingsområder og realiseres gennem vurderinger, beslutninger og handlinger i relation til kendte og ukendte situationer."}

Rammen er således udformet som en række kompetencer, der understøttes af viden, færdigheder, følelser og personlige ressourcer.

Viden og færdigheder er som udgangspunkt konkrete og, om ikke altid målbare, så mulige at iagttage og mulige at opstille i en taksonomi. Anderledes forholder det sig med de personlige og subjektive ressourcer, som ikke er noget, man kan undervise i, teste og evaluere. Eksempelvis er det formentlig en væsentlig ressource "at være udholdende", men man kan ikke undervise i at være udholdende, men er henvist til at træne udholdenhed gennem de metoder og aktiviteter, der anvendes $\mathrm{i}$ undervisningen. Derfor beror denne del af kompetencerammen mere på metode og didaktisk tilgang end de mere konkrete videns- og færdighedsområder. 


\section{Forskning}

Forskningsmæssigt er der ikke enighed om, hvilken viden hvilke færdigheder og personlige ressourcer der konstituerer entreprenørielle kompetencer. Ligeledes er der ikke enighed om, hvordan disse kompetencer skal opbygges. Der findes dog nogle centrale områder, der træder frem, og som angår både indholdet og den pædagogiske form. ${ }^{9}$ Det gælder:

- Betoningen af handlingsaspektet, og at entreprenørskabsundervisning skal baseres på elevernes faktiske handlinger og aktive deltagelse.

- Kreativitet og evnen til at se, sanse og skabe muligheder samt evnen til problemløsning, divergent tænkning og at kunne eksperimentere med forskellige vidensformer.

- Viden om, forståelsen af og interaktion med kultur, omverden og eksterne parter.

- Elevers subjektive tro på og tillid til egne muligheder for, og ressourcer til, at kunne agere i verden og udfolde drømme og visioner, herunder vedholdenhed og evnen til at agere i usikre kontekster.

\section{Nordiske strategier og dannelsesmål}

I de nordiske landes overordnede skoleformål og i de nationale entreprenørskabsstrategier indgår en lang række videns- færdigheds og kompetencemål, som direkte eller indirekte er relateret til entreprenørskab. Nogle af områderne vedrører noget ydre som eleverne skal kende til: "kreative arbejdsmetoder, forretningsudvikling, økonomi, projektstyring, netværk", og noget de skal kunne håndtere: "tage initiativ, ansvar, omsætte ideer til handling, beslutningstagning, kommunikation, samarbejde og problemløsning”. Andre områder angår det indre og dermed emotionelle og personligt forankrede ressourcer eksempelvis: "Forholde sig åbent til muligheder, udholdenhed og vedholdenhed, nysgerrighed, selvtillid, kreativitet og mod til at tage risiko, anvende fantasi for at overskride eksisterende grænser". Herudover er der en række normative eller etiske udsagn som at: "Bidrage til en holdbar fremtid".

\section{Referencegruppens bidrag}

Referencegruppen leverede en lang række bidrag, som angår viden, færdigheder og kompetencer. Som i de overordnede formålsbeskrivelser for skolen, er der også her tale om meget varierende videns- færdigheds- og kompetencemål, der angår såvel noget ydre som noget indre eksempelvis: "Mig selv som entreprenøriel person, hvordan samfundet er opbygget og fungerer, præsentere mig selv og mine ideer, se behov og finde på løsninger, kreativt håndtere usikkerhed, identificere muligheder og være proaktiv, viden om lokalsamfund, landet og verden".

Der viser sig også et varierende fokus på "progression og taksonomi” (DK), en særlig form for "pædagogisk entreprenørskab" (N) og en særlig tilgang som "entreprenørielt lærende" (S). De forskellige tilgange viser at de nordiske landes forholdsvis enslydende strategier har resulteret i en stor diversitet i aktiviteter og praksisformer.

\footnotetext{
${ }^{8}$ Illeris (2013) Kompetence - Hvad, hvorfor, hvordan?, Samfundslitteratur.

${ }^{9}$ Nybye \& Rasmussen (2013) Progressionsmodel for innovations og entreprenørskabsundervisning, Fonden for Entreprenørskab.
} 


\section{Kompetenceramme}

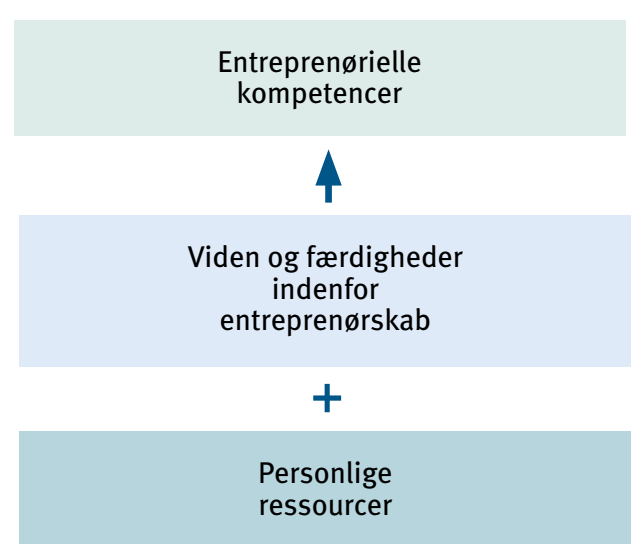

Ved at samle de forskellige bidrag og udsagn fra forskning, nordiske skoleformål og referencegruppen fremkommer fire kompetencer, hvoraf de tre kan baseres på viden og færdigheder. Det fjerde område angår de personlige ressourcer og fungerer som et fundament for at sætte de øvrige områder i spil. For således at kunne gennemføre handlinger i verden skal der mod, ansvar, accept af fejl etc. til. Omvendt vil personlige ressourcer i sig selv ikke nødvendigvis føre til en kvalificeret handling eller til entreprenøriel kompetence og dannelse.

1. Handlingskompetence: Planlægge, strukturere, udføre, samarbejde, kommunikere og håndtere økonomi og ressourcer.

2. Kreativitetskompetence: At skabe, overskride, tænke divergent, tænke på tværs, opstille drømme, sanse, eksperimentere, problemløse og vurdere.

3. Omverdenskompetence: Viden om kulturformer, globalisering, samfundets indretning, forretningsforståelse, sociale forhold, netværk, evnen til at opfatte og navigere i en kompleks samtid. Måden hvorpå vi opfatter vores verden og vores omgivelser, de indtryk vi er modtagelige for.
4. Personlige ressourcer: Mod, selvtillid, vedholdenhed, håndtering af kompleksitet og usikkerhed, acceptere fejl, initiativ, ansvar og selvstændighed.

Entreprenørielle kompetencer dannes således som et produkt af viden og færdigheder indenfor, handling, kreativitet og omverden, med en række personlige ressourcer som forudsætning.

Kompetencerammen er lavet på 3 niveauer:

3. klassetrin/indskoling, 6. klassetrin/mellemtrin og 9. klassetrin/udskoling. Viden, færdigheder og kompetencer er på alle tre niveauer udtryk for et idealbillede og et slutmål. 


\begin{tabular}{|c|c|c|c|c|c|}
\hline \multicolumn{2}{|c|}{$\begin{array}{l}\text { Handlingskompetence } \\
\text { Eleven kan samarbejde om opgaver, og } \\
\text { med støtte udføre simple projekter på } \\
\text { skolen og i nærmiljøet }\end{array}$} & \multicolumn{2}{|c|}{$\begin{array}{l}\text { Kreativitetskompetence } \\
\text { Eleven kan arbejde eksperimenterende } \\
\text { og undersøgende i simple kreative } \\
\text { processer, og kan forholde sig til resul- } \\
\text { taterne ved brug af grundlæggende } \\
\text { faglig viden }\end{array}$} & \multicolumn{2}{|c|}{$\begin{array}{l}\text { Omverdenskompetence } \\
\text { Eleven har begyndende forståelse af } \\
\text { egen identitet og kulturel baggrund } \\
\text { og kan orientere sig i simple lokale } \\
\text { kontekster }\end{array}$} \\
\hline Færdighed, kan & Viden om & Færdighed, kan & Viden om & Færdighed, kan & Viden om \\
\hline $\begin{array}{l}\text { Deltage i simple } \\
\text { projekter } \\
\text { Indgå i simple } \\
\text { samarbejdsrela- } \\
\text { tioner } \\
\text { Præsentere egne } \\
\text { resultater og } \\
\text { produkter i skole } \\
\text { og nærmiljø } \\
\text { Tage kontakt til } \\
\text { personligt netværk } \\
\text { Arbejde med simp- } \\
\text { le visualiseringer } \\
\text { og modeller } \\
\text { Etablere udstil- } \\
\text { linger af fælles } \\
\text { projekter }\end{array}$ & $\begin{array}{l}\text { Planlægning og } \\
\text { målsætning } \\
\text { At arbejde sam- } \\
\text { men med andre } \\
\text { Kommunikation } \\
\text { og simple præsen- } \\
\text { tationsformer } \\
\text { Personligt net- } \\
\text { værk } \\
\text { Repræsentationer } \\
\text { og modeller }\end{array}$ & $\begin{array}{l}\text { Anvende fantasi } \\
\text { og kreativitet i } \\
\text { forbindelse med } \\
\text { undervisning og } \\
\text { aktiviteter } \\
\text { Kombinere for- } \\
\text { skellige videns- } \\
\text { områder } \\
\text { Lege med viden } \\
\text { Deltage i simple } \\
\text { idegenererings } \\
\text { processer } \\
\text { Deltage i samtaler } \\
\text { om vurdering af } \\
\text { ideer } \\
\text { Anvende sanse- } \\
\text { lige begreber og } \\
\text { billedsprog }\end{array}$ & $\begin{array}{l}\text { Fantasi og } \\
\text { kreativitet } \\
\text { Simple kreative } \\
\text { processer } \\
\text { Enkel ide- } \\
\text { generering } \\
\text { Sanselighed og } \\
\text { enkel æstetik }\end{array}$ & $\begin{array}{l}\text { Beskrive egen } \\
\text { kultur } \\
\text { Anvende pengebe- } \\
\text { grebet i enkle } \\
\text { matematiske } \\
\text { beregninger } \\
\text { Samtale om } \\
\text { muligheder og } \\
\text { udfordringer i } \\
\text { nærmiljøet }\end{array}$ & $\begin{array}{l}\begin{array}{l}\text { Egen og andres } \\
\text { kulturer }\end{array} \\
\text { Pengebegrebet } \\
\text { Fritids- og } \\
\text { arbejdsliv } \\
\text { Virksomheder og } \\
\text { institutioner } \\
\text { i nærmiljøet }\end{array}$ \\
\hline
\end{tabular}




\section{6. klasse}

\begin{tabular}{|c|c|c|c|c|c|}
\hline \multicolumn{2}{|c|}{$\begin{array}{l}\text { Handlingskompetence } \\
\text { Eleven kan i samarbejde med andre tage } \\
\text { initiativ til, planlægge, organisere og ud- } \\
\text { føre enkle projekter i en konkret kontekst }\end{array}$} & \multicolumn{2}{|c|}{$\begin{array}{l}\text { Kreativitetskompetence } \\
\text { Eleven kan arbejde selvstændigt, ekspe- } \\
\text { rimenterende og undersøgende i kreative } \\
\text { processer, og vurdere resultaterne ud fra } \\
\text { faglig viden og æstetiske kriterier }\end{array}$} & \multicolumn{2}{|c|}{$\begin{array}{l}\text { Omverdenskompetence } \\
\text { Eleven kan på baggrund af forståelse } \\
\text { af egen identitet og kulturel baggrund } \\
\text { orientere sig i forskellige teknologi- } \\
\text { ske, økonomiske, kulturelle og sociale } \\
\text { kontekster }\end{array}$} \\
\hline Færdighed, kan & Viden om & Færdighed, kan & Viden om & Færdighed, kan & Viden om \\
\hline $\begin{array}{l}\text { Beskrive usikker- } \\
\text { hed i forbindelse } \\
\text { med projekter } \\
\text { Indgå aktivt i } \\
\text { projekter } \\
\text { Anvende person- } \\
\text { ligt netværk } \\
\text { Indgå i sam- } \\
\text { arbejdsrelationer } \\
\text { Præsentere resul- } \\
\text { tater og projekter } \\
\text { Formidle viden } \\
\text { gennem modeller, } \\
\text { skitser og visuelle } \\
\text { udtryk }\end{array}$ & $\begin{array}{l}\text { Enkel projekt- } \\
\text { styring, planlæg- } \\
\text { ning, risici og } \\
\text { ressourcer } \\
\text { Enkle samarbejds- } \\
\text { former } \\
\text { Kommunikation, } \\
\text { præsentations- } \\
\text { former og virke- } \\
\text { midler } \\
\text { Personligt og } \\
\text { skolebaseret } \\
\text { netværk } \\
\text { Modeller, sym- } \\
\text { boler og visuelle } \\
\text { udtryk }\end{array}$ & $\begin{array}{l}\text { Kombinere faglige } \\
\text { vidensområder } \\
\text { Eksperimentere } \\
\text { med viden } \\
\text { Indgå i faglig } \\
\text { problemløsning } \\
\text { Arbejde i kreative } \\
\text { processer } \\
\text { Deltage i ide- } \\
\text { generering } \\
\text { Samtale om } \\
\text { vurdering af ideer } \\
\text { Anvende sanse- } \\
\text { lige begreber } \\
\text { Samtale om } \\
\text { drømme for den } \\
\text { nærmeste fremtid }\end{array}$ & $\begin{array}{l}\text { Fantasi og kreati- } \\
\text { vitet i forbindelse } \\
\text { med forskellige } \\
\text { fagområder } \\
\text { Kreative processer } \\
\text { Degenererings- } \\
\text { former } \\
\text { Sanselighed og } \\
\text { æstetik }\end{array}$ & $\begin{array}{l}\text { Sammenligne } \\
\text { kulturer } \\
\text { Samtale om } \\
\text { muligheder og } \\
\text { problemstillinger i } \\
\text { verden } \\
\text { Diskutere egne } \\
\text { forståelse af } \\
\text { verden } \\
\text { Opstille simple } \\
\text { budgetter } \\
\text { Beskrive økonomi } \\
\text { og andre ressour- } \\
\text { cer i samfundet } \\
\text { Beskrive hvordan } \\
\text { en virksomhed } \\
\text { fungerer }\end{array}$ & $\begin{array}{l}\begin{array}{l}\text { Forskelle på } \\
\text { kulturer }\end{array} \\
\text { Samfundets } \\
\text { opbygning og } \\
\text { indretning } \\
\text { Økonomi og } \\
\text { forskellige } \\
\text { ressourcer } \\
\text { Skole, fritids- og } \\
\text { arbejdsliv } \\
\text { Virksomheder } \\
\text { og institutioner } \\
\text { indenfor lokal- } \\
\text { området }\end{array}$ \\
\hline & Forandrings & $\begin{array}{l}\text { PERSONLIG } \\
\text { g vilje til at udfordr } \\
\text { Ansvar i forhold til } \\
\text { Selvtillid i fort } \\
\text { Tage initiativer } \\
\text { i forhold til egne ar } \\
\text { - og vedholdenhed } \\
\text { ccept af egne og an } \\
\text { Håndtere usikker } \\
\text { sere på opgaver og }\end{array}$ & $\begin{array}{l}\text { ESSOURCER } \\
\text { g selv og sine kamm } \\
\text { e og fælles projekter } \\
\text { til egne evner } \\
\text { imen med andre } \\
\text { dsformer, meninger } \\
\text { engerevarende tidsru } \\
\text { fejl og misforståels } \\
\text { i kortere tidsrum } \\
\text { ordringer over længe }\end{array}$ & synspunkter & \\
\hline
\end{tabular}




\section{9. klasse}

\section{Handlingskompetence}

Eleven kan i samarbejde med andre tage initiativ til og planlægge, tage ansvar for, lede, organisere og udføre projekter i en konkret kontekst

\section{Kreativitetskompetence}

Eleven kan selvstændigt, vedholdende, eksperimenterende og undersøgende i kreative processer, og vurdere resultaterne ud fra faglig viden, erfaringer og æstetiske kriterier

\section{Omverdenskompetence}

Eleven kan på baggrund af forståelse af egen identitet og kulturel baggrund orientere sig i og vurdere teknologiske, økonomiske, kulturelle og sociale kontekster

\begin{tabular}{|c|c|c|c|c|c|}
\hline Færdighed, kan & Viden om & Færdighed, kan & Viden om & Færdighed, kan & Viden om \\
\hline $\begin{array}{l}\text { Håndtere projekter } \\
\text { sammen med } \\
\text { andre } \\
\text { Vurdere usikker- } \\
\text { hed og risici i } \\
\text { forbindelse med } \\
\text { projekter } \\
\text { Indgå i forskellige } \\
\text { samarbejds- } \\
\text { relationer } \\
\text { Tage kontakter } \\
\text { udenfor personligt } \\
\text { netværk } \\
\text { Opbygge og } \\
\text { anvende eget } \\
\text { netværk } \\
\text { Præsentere resul- } \\
\text { tater og projekter } \\
\text { for en specifik } \\
\text { målgruppe }\end{array}$ & $\begin{array}{l}\text { Projektstyring, } \\
\text { planlægning, inte- } \\
\text { ressenter, risici og } \\
\text { ressourcer } \\
\text { Samarbejds- } \\
\text { former og } \\
\text { processer } \\
\text { Personlige og } \\
\text { professionelle } \\
\text { netværk } \\
\text { Kommunikation, } \\
\text { præsentations- } \\
\text { former og virke- } \\
\text { midler }\end{array}$ & $\begin{array}{l}\text { Kombinere } \\
\text { forskellige faglige } \\
\text { vidensområder } \\
\text { Eksperimentere } \\
\text { med viden og } \\
\text { faglighed } \\
\text { Arbejde med } \\
\text { faglig problem- } \\
\text { løsning } \\
\text { Strukturere } \\
\text { idegenererings- } \\
\text { processer } \\
\text { Arbejde i for- } \\
\text { skellige kreative } \\
\text { processer } \\
\text { Diskutere vurde- } \\
\text { ringer af ideer } \\
\text { Anvende sanse- } \\
\text { lige begreber i } \\
\text { relation til faglig } \\
\text { viden } \\
\text { Opstille drømme } \\
\text { og visioner for } \\
\text { fremtiden }\end{array}$ & $\begin{array}{l}\text { Fantasi og kreati- } \\
\text { vitet i samfundet } \\
\text { Kreative processer } \\
\text { Forskellige ide- } \\
\text { genereringsformer } \\
\text { Sanselighed og } \\
\text { æstetik } \\
\text { Kreativitet i rela- } \\
\text { tion til faglighed }\end{array}$ & $\begin{array}{l}\text { Beskrive og sam- } \\
\text { menligne kulturer } \\
\text { Beskrive mulig- } \\
\text { heder og pro- } \\
\text { blemstillinger ved } \\
\text { globalisering } \\
\text { Opstille simple } \\
\text { budgetter og } \\
\text { regnskaber } \\
\text { Analysere og be- } \\
\text { skrive ressourcer } \\
\text { Beskrive enkle for- } \\
\text { retningsmodeller } \\
\text { Udfordre eksiste- } \\
\text { rende forståelser } \\
\text { af verden }\end{array}$ & $\begin{array}{l}\text { Forskellige } \\
\text { kulturer } \\
\text { Globalisering og } \\
\text { konsekvenser } \\
\text { Samfundets } \\
\text { opbygning, } \\
\text { indretning, pro- } \\
\text { blemstillinger og } \\
\text { muligheder } \\
\text { Arbejdsliv og } \\
\text { karriere- } \\
\text { muligheder } \\
\text { Økonomi og } \\
\text { ressourcer }\end{array}$ \\
\hline \multicolumn{6}{|c|}{$\begin{array}{l}\text { PERSONLIGE RESSOURCER } \\
\text { d og vilje til at udfordre sig selv og andre } \\
\text { Isvar i forhold til egne og fælles projekter } \\
\text { forhold til egne vurderinger evner og potentialer } \\
\text { itiativer selvstændigt og sammen med andre } \\
\text { svilje i forhold til eksisterende opfattelser og vaner } \\
\text { holdenhed i længerevarende og afbrudte tidsrum } \\
\text { læring af egne og andres fejl og misforståelser } \\
\text { Overskue usikre og komplekse opgaver } \\
\text { på afbrudte opgaver og projekter over længere tid }\end{array}$} \\
\hline
\end{tabular}




\section{Entreprenørielle kompetencer i den pædagogiske praksis}

Entreprenørskab er ikke et fag i de nordiske skoler, og de entreprenørielle kompetencer må derfor opbygges som del af de eksisterende fag og som særlige entreprenørielle undervisningsforløb. Det betyder, at lærerne må kunne sammentænke skolens fag og udviklingen af entreprenørielle kompetencer, så entreprenørskab bliver en del af skolens dagligdag. Samtidig må skolerne sikre, at eleverne får mulighed for at deltage i sammenhængende entreprenørielle forløb, hvor kompetencerne sættes i spil, gerne i en værdisskabende praksis.

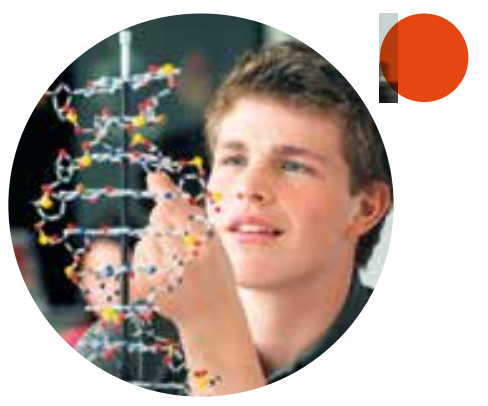




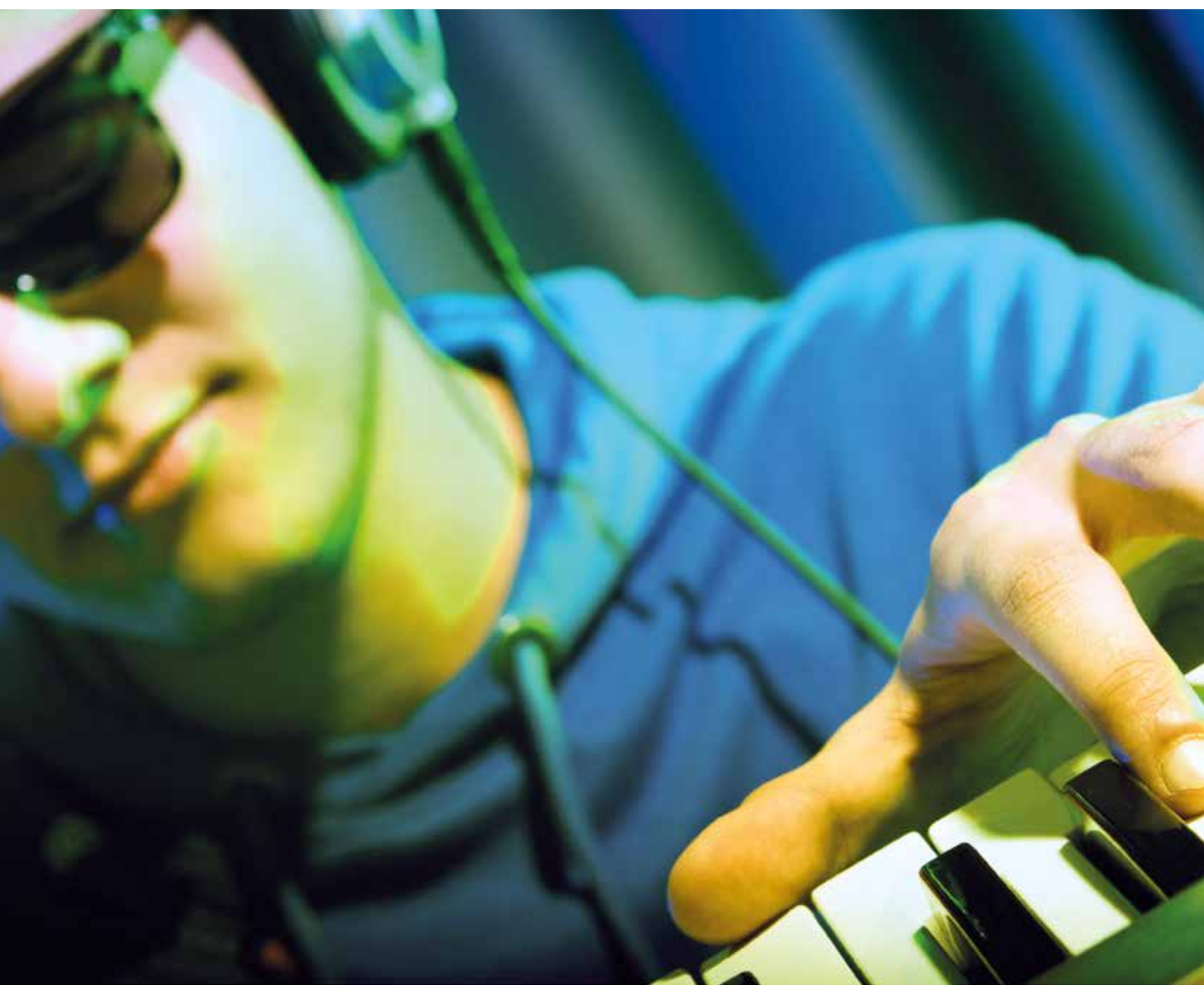




\section{Didaktiske principper}

I det følgende er der opstillet en række didaktiske principper som kan understøtte udviklingen af elevernes kompetencer og af deres personlige ressourcer. Didaktik angår sammenhængen der er imellem undervisningens mål, indhold og metode, og som sandsynliggør at eleverne lærer det ønskede og samtidig understøtter elevernes videre udvikling og læring. Didaktiske principper er således redskaber til lærernes planlægning af undervisning, og påvirker måden som undervisningen rammesættes, organiseres og udføres på. Ideen bag principperne er at disse er uafhængige af klassetrin, niveau og faglige kontekster, og at de kan lette oversættelsesarbejdet fra kompetencemål til praksis og omvendt. Principperne kan inddrages enkeltvis eller flere ad gangen, men det vil formentlig ikke være hensigtsmæssigt eller muligt at anvende alle principper på en gang.

\section{Principper der understøtter udviklingen af handlingskompetence}

- At arbejde med værdiskabende ${ }^{10} /$ forandrende aktiviteter.

- At arbejde med involvering og elevinddragelse.

- At give eleverne ansvar for aktiviteter.

- At anvende viden og færdigheder i forskellige kontekster.

- At tage afsæt i forskellige kontekster for aktiviteter.

- At anvende netværk og relationer.

- At stimulere varierende samarbejdsformer.

- At stimulere varierende præsentationsformer.

- At stimulere refleksion i forhold til handling.

\section{Principper der understøtter udviklingen af kreative kompetencer}

- At arbejde med eksperimenterende aktiviteter.

- At skabe tidsrum uden bedømmelse.

- At arbejde med skabende aktiviteter.

- At sikre fordybelsestid.

- At stille åbne / umulige opgaver.

- At overraske og etablere det uventede.

- At involvere flere sanser.

- At invitere til refleksion i forhold til fantasi og kreativitet.

\footnotetext{
${ }^{10}$ Værdiskabelse adskiller entreprenørielle undervisningsforløb fra andre processuelle undervisningsformer, eksempelvis problemorienteret projektundervisning eller emnearbejde. Med værdiskabende menes at aktiviteten skaber værdi for andre, udover elevernes egen læring. Med andre ord gør aktiviteterne en form for gavn i verden, enten reelt som konkrete aktiviteter, eller potentielt som planer, modeller etc.
} 


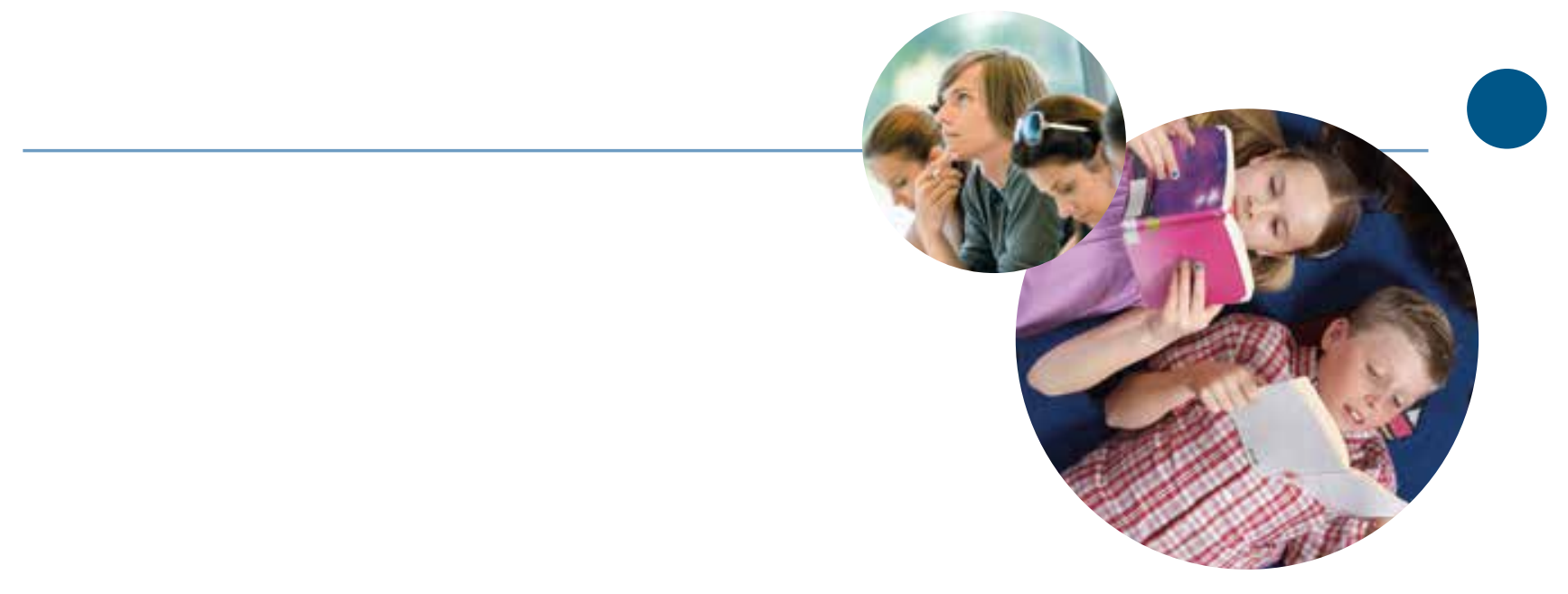

\section{Principper der understøtter udviklingen af} omverdenskompetence

- At stimulere nysgerrighed og undren.

- At involvere aktuelle temaer.

- At perspektivere faglighed, viden og færdigheder.

- At involvere sociale, økonomiske og kulturelle kontekster.

- At sikre interaktion imellem individ, skole og omverden.

- At opsøge viden og feedback fra omverden.

- At italesætte verden som mulighed.

- At stimulere refleksion i forhold til skolens omverden.

\section{Principper der understøtter udviklingen af personlige ressourcer}

- At sikre succesoplevelser.

- At stille tilpas ${ }^{11}$ udfordrende opgaver.

- At skabe rum for en anerkendende tilgang.

- At arbejde bevidst med usikkerhed.

- At arbejde med involvering og elevinddragelse.

- At understøtte og vejlede.

- At invitere til refleksion over personlige ressourcer.

${ }^{11}$ På svensk: lämpliga. Eleverne skal "stå på tæer - men ikke for længe". 


\section{Eksempler på anvendelse af de didaktiske principper}

Eksemplerne er udarbejdet af praktikere og er afprøvet på danske skoler, hvorfor fag og de overordnede kompetenceområder er hentet fra de danske "fælles mål" for undervisningen. Forløbene er ganske almindelige undervisningsforløb, som med anvendelse af de didaktiske principper udover de faglige mål også understøtter udviklingen af entreprenørielle kompetencer.

\section{Biodiversitet, 3. klasse}

I forløbet indgår faglige mål fra faget "Natur/Teknologi" herunder kompetenceområderne "undersøgelse" og "kommunikation".

Forløbet starter med formidling af begrebet biodiversitet. Herefter skal eleverne selvstændigt undersøge forskellige databaser om dyr og habitater (princippet om at opsøge viden og feedback fra omverden). Efterfølgende planlægger elever og læreren i samarbejde en udflugt (princippet om elevinddragelse og involvering), hvor eleverne i små grupper går på jagt efter dyr i nærmiljøet (princippet om at stimulere nysgerrighed og undren) med særligt henblik på at kende habitater og fauna i nærområdet (princippet om inddragelse af kontekster). Eleverne skal herefter udvælge et bestemt dyr, og lave faglige undersøgelser, (princippet om at skabe plads til fordybelse) skitser og tegninger (princippet om involvering af flere sanser) med henblik på at lave faglige præsentationer (princippet om at arbejde bevidst med usikkerhed). Under præsentationerne er de andre elever instrueret $\mathrm{i}$ at rose og komme med ideer til forbedringer og det videre arbejde (princippet om at skabe rum for en anerkendende tilgang) Som afslutning diskuteres ideer til, hvordan eleverne kan være med til at sikre biodiver- sitet i deres nærmiljø (princippet om at italesætte verden som mulighed).

\section{Vennemøbel, 6.klasse}

I forløbet indgår faglige mål fra faget "Håndværk og Design", herunder kompetenceområderne "Forarbejdning", "Materialer" og "Design".

Eleverne får til opgave at lave et "møbel" som er godt, når man skal være sammen med venner. Forløbet starter med diskussioner og læreroplæg om møblers historie og baggrund samt designmæssige udviklinger, hvor møbler både er brugsgenstande, varer og kunstværker (princippet om at perspektivere faglighed, viden og færdigheder). Eleverne skal herefter besøge en møbelforretning (gerne i virkeligheden, alternativt virtuelt) og undersøge forskellige designs, materialer og egenskaber (princippet om at opsøge viden og feedback fra omverden/ princippet om at sikre interaktion imellem individ, skole og omverden). De udvælger et møbel med henblik på at beskrive det på skrift (princippet om at anvende viden og færdigheder i forskellige kontekster). Efterfølgende arbejder eleverne med at udvikle ideer til deres egne møbler ud fra en ramme, hvor møblet skal danne ramme for at være sammen med venner og at kunne lære sammen (princippet om åbne / umulige opgaver). Herefter bygger eleverne modeller af møblerne i et fast størrelsesforhold (princippet om at inddrage flere sanser) og giver hinanden konstruktiv feedback (princippet om at skabe tidsrum uden bedømmelse). Som afslutning skal eleverne undersøge, hvordan modellen kan blive til et konkret produkt og undersøge, hvordan man kan skabe en virksomhed ud fra en produktion (princippet om at stimulere 


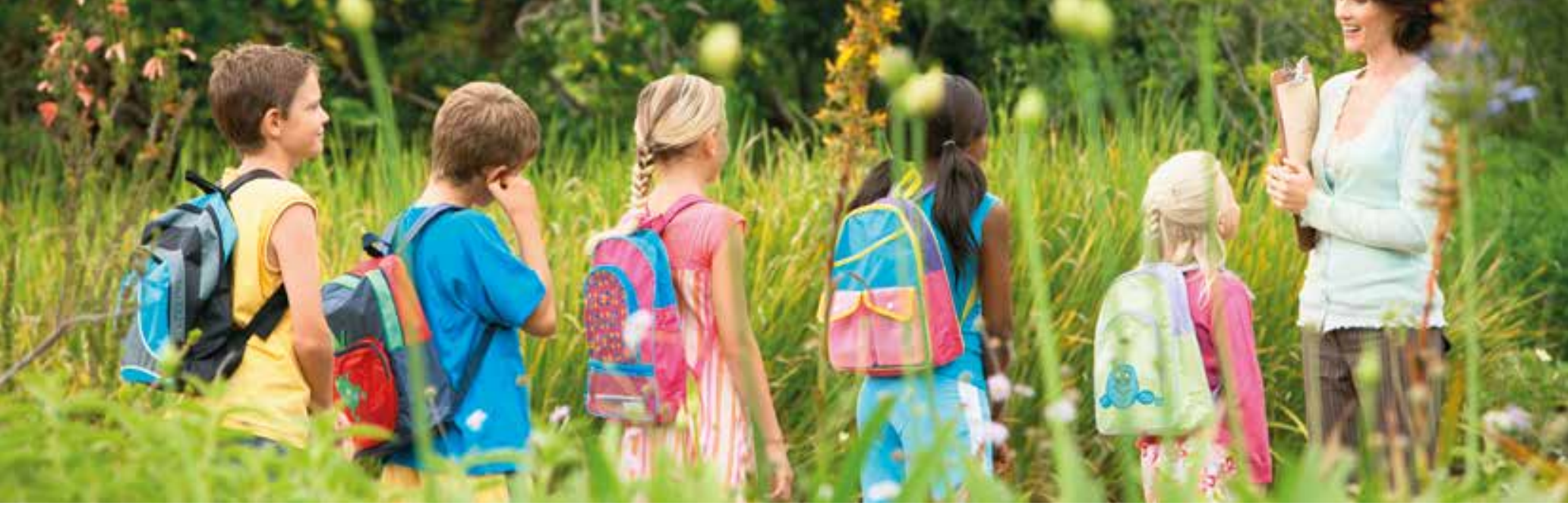

refleksion i forhold til handling). Som afslutning laver og $\emptyset$ ver eleverne en salgstale for produktet.

\section{Anvendt matematik, 8.klasse}

I forløbet indgår faglige mål for faget matematik herunder kompetenceområdet "matematisk kompetence".

Som start på forløbet inddeles eleverne i mindre grupper, og hver gruppe får en hverdagsgenstand f.eks. en mælkekarton, et cykelhjul, et glas, en avis, udleveret (princippet om at overraske og etablere det uventede). Eleverne gives derefter en opgave som går ud på at få så meget matematik som overhovedet muligt ud af den udleverede genstand (princippet om at stille åbne / umulige opgaver, princippet om at arbejde med eksperimenterende aktiviteter) eleverne arbejder herefter selvstændigt med opgaven, og læreren udfordrer, kommenterer og støtter eleverne undervejs (princippet om at vejlede og understøtte). På baggrund af elevernes resultater udarbejder de matematiske opgaver som de giver til de andre grupper, således at grupperne bytter opgaver og genstande. Afslutningsvis sammenligner grupperne deres resultater og udregninger og giver feedback på arbejdet (princippet om at skabe rum for en anerkendende tilgang).

\section{Reklamer, 9. klasse}

I forløbet indgår faglige mål for faget dansk herunder kompetenceområderne "fremstilling", "fortolkning" og "kommunikation".

Som start på forløbet skal eleverne undersøge konkrete reklamer i nærmiljøet, tage billeder af dem og efterfølgende analysere disse med faglige modeller og begreber, og foretage en samlet vurdering af reklamer i forhold til modtagergruppe (princippet om at stimulere undren og nysgerrighed) Eleverne skal efterfølgende lave et struktureret interview med afsenderen/virksomheden (princippet om bevidst usikkerhed). Eleverne udvikler herefter forskellige bud (princippet om arbejde med eksperimenterende aktiviteter) på andre reklamer/logoer for de analyserede virksomheder (princippet om at arbejde med værdiskabende / forandrende aktiviteter). Efterfølgende etableres en udstilling, hvor eleverne præsenterer viden og produkter for en fagperson, som vurderer produkterne og giver dem feedback (princippet om at sikre interaktion imellem individ, skole og samfund). Forløbet afsluttes med en fælles samtale og refleksion over forløbet, kontakten med omverden og den faglige læring (princippet om at invitere til refleksion). 


\section{norden}

\section{Nordisk Ministerråd}

\section{Ved Stranden 18}

DK-1061 København K

www.norden.org

Nordisk Ministerråd har i flere faser arbejdet for at styrke entreprenørskabskultur- og uddannelse i de nordiske lande. Globalisering, teknologisk udvikling, forandringshastighed og demografiske ændringer udfordrer såvel den nordiske velfærdsmodel som det enkelte individ.

Kompetencerammen henvender sig til en lang række interessenter: Den er først og fremmest et redskab til lærere og praktikere som kan finde kompetence- og læringsmål samt didaktiske principper for undervisningen. Kompetencerammen henvender sig også til beslutningstagere, som skal skabe lovgivning og rammer for at entreprenørskabsundervisning kan finde sted. På samme måde henvender den sig til ledere der i dagligdagen skal understøtte strukturer og skabe miljøer samt pædagogisk udvikling så entreprenørskabsundervisning bliver en integreret del af grundskolen.

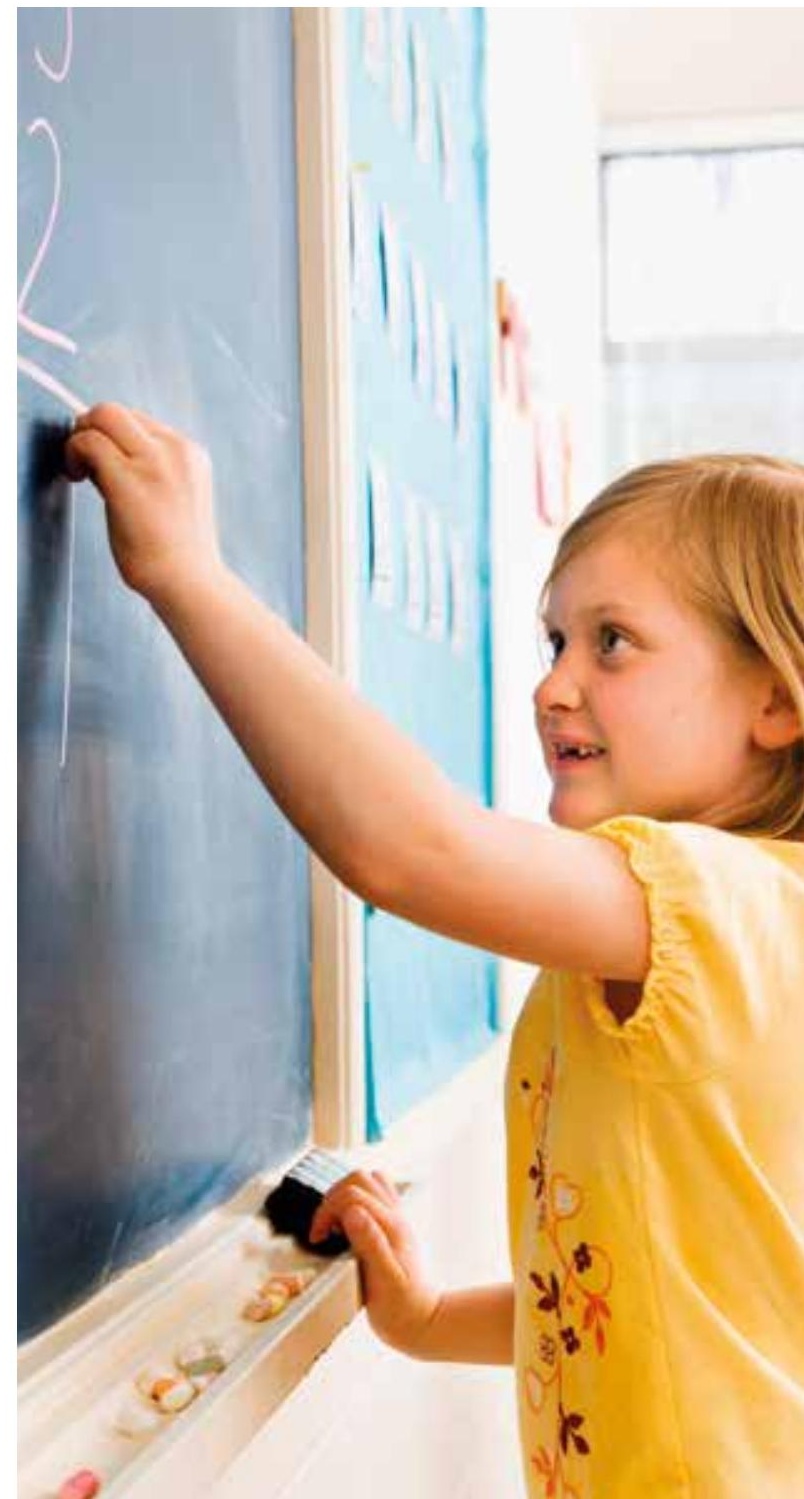

